\title{
The Recovery Kinetics of Lymphohematopoietic Tissues in NFS Mice after Split-dose $\mathbf{X}$-irradiation
}

\author{
Nobuko MORI, Yasuhiko TAKAMORI*, Masaaki OKUMOTO, \\ and Ryosuke NISHIKAWA \\ Department of Applied Bioscience, Research Institute for Advanced Science and Technology, \\ University of Osaka Prefecture and *Laboratory of Veterinary Radiology, \\ College of Agriculture, University of Osaka Prefecture, \\ 1-1 Gakuen-cho, Sakai-shi, Osaka 593, Japan
}

(Received 13 January 1993/Accepted 22 June 1993)

\begin{abstract}
The recovery kinetics of lymphohematopoietic tissues was studied after split doses ( $4 \mathrm{X}$ $1.7 \mathrm{~Gy}$ ) of X-irradiation in NFS mice, which are highly susceptible to radiation-induced lymphoma. Thymic and splenic weights had decreased to a similar extent $(42 \%$ and $43 \%$ of normal) 24 hours after irradiation. Thymic weight began to recover after a continuous decrease for 3 weeks and had attained an almost normal level by 8 weeks after irradiation. In contrast, splenic weight had recovered to more than $70 \%$ of the control 1 week after irradiation but recovery was delayed thereafter. The number of thymocytes was remarkably reduced ( $26 \%$ of the normal) 24 hours after the last irradiation and was still significantly lower $(60 \%$ and $69 \%)$ than normal 4 and 8 weeks after irradiation. The nucleated marrow cell number was not as significantly reduced $(56 \%$ of normal) as thymocyte number 24 hours after exposure and had recovered to an almost normal level by $4-6$ weeks after irradiation. The number of femoral CFU-S (spleen colony-forming units) had decreased to $1.7 \%$ of the normal level by 24 hours after the last exposure, then showed logarithmic growth. However, recovery ceased 6 weeks after irradiation, at which point the CFU-S number was about $60 \%$ of the normal level. These results suggest that disordered lymphohematopoiesis in the thymus, spleen and bone marrow persists for an extended period of time and that this disorder occurrs in connection with a reduction in the femoral CFU-S number.-KEY WORDS : CFU-S, lymphomagenesis, mice, recovery of hematopoietic tissues, $\mathrm{X}$-irradiation
\end{abstract}

Split doses (4 X 1.7 Gy) of whole-body Xirradiation efficiently induce thymic lymphomas in susceptible strains of mice after a long latent period [7]. Development of lymphomas after $\mathrm{X}$-irradiation is significantly affected by the interaction between the thymus and bone marrow. Thymectomy and bone marrow reconstitution immediately after the final exposure can effectively prevent the development of lymphoma $[6,8,18]$. Since HaranGhera first reported that initial transformation of lymphocytes occurs in the bone marrow prior to neoplastic progression in the thymus, there has long been controversy as to whether the primary site of radiation lymphomagenesis is the bone marrow or the thymus $[1,4]$. By the use of intrathymic transplantation assay sys- tems, transformed cells were detected primarily in the thymus within 10 days after the final exposure to radiation [11]. However, these transformed cells disappear if normal marrow cells are grafted into the mice immediately after irradiation [3]. These facts suggest that marrow-thymus interactions play a significant role in the generation of thymic lymphoma after radiation.

NFS mice are very susceptible to radiation induction of thymic lymphoma $[12,13]$. Tumors begin to arise in NFS mice about 3 months after split doses of $\mathrm{X}$-irradiation and the cumulative incidence of lymphomas eventually amounts to around $90 \%$ [9]. Thus, NFS mice provide a suitable model for studying the mechanism of radiation-induced lymphomagenesis. 


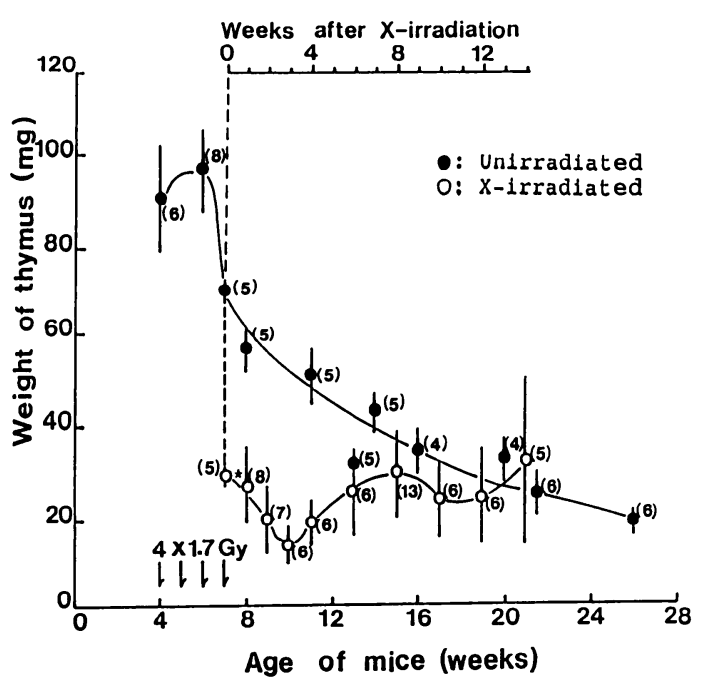

Fig. 1. Thymic weight changes in NFS mice exposed to $4 \mathrm{X} 1.7 \mathrm{~Gy}$ of $\mathrm{X}$-irradiation. Mean $\pm \mathrm{SD}$. The value with an asterisk was assessed 24 hours after irradiation. Numbers of mice used are shown in parentheses.

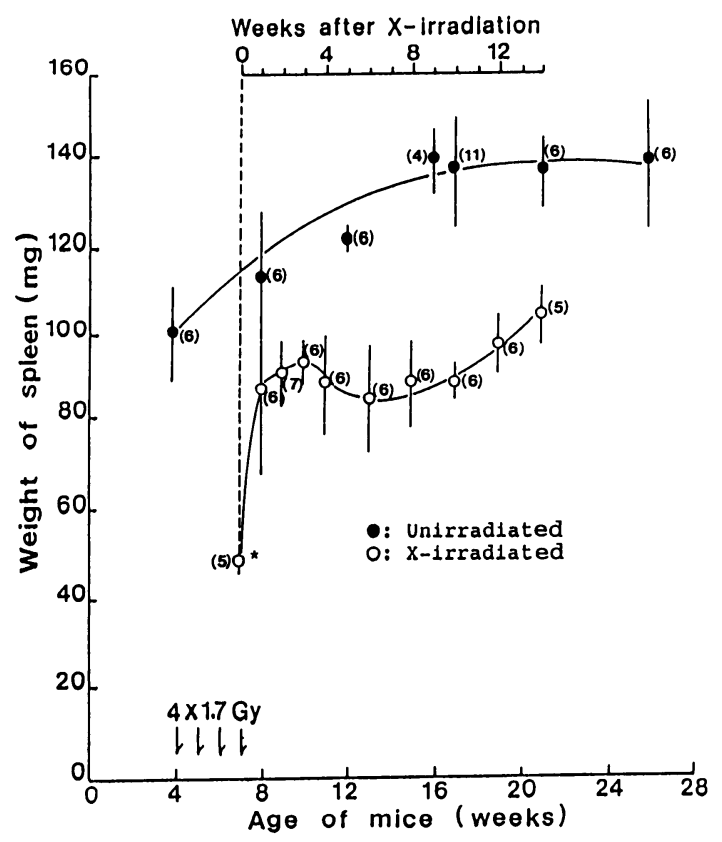

Fig. 2. Splenic weight changes in NFS mice exposed to $4 \mathrm{X} 1.7 \mathrm{~Gy}$ of $\mathrm{X}$-irradiation. Mean $\pm \mathrm{SD}$. The value with an asterisk was assessed 24 hours after irradiation. Numbers of mice used are shown in parentheses.
In this study, we examined the effects of leukemogenic split doses of $\mathrm{X}$-irradiation on lymphohematopoietic tissues (thymus, spleen and bone marrow) in NFS mice during the 3 month period following exposure. The possible significance of marrow-thymus interactions in radiation-induced lymphomagenesis is discussed in this report.

\section{Materials and Methods}

Animals : Male and female NFS mice were used in this study. The origin of NFS mice was previously described [13]. All mice used in the experiments were bred in our own colonies, in the University of Osaka Prefecture. Mice were kept in a room with a 12 hours/day light cycle and a temperature of $24 \pm 0.5^{\circ} \mathrm{C}$, fed commercial MF diet (Oriental Yeast Co. Ltd., Tokyo) and supplied with tap water ad libitum.

$\mathrm{X}$-irradiation and the experimental procedure : $\mathrm{X}$-irradiation of mice was carried out at a rate of $0.5 \mathrm{~Gy} / \mathrm{min}$ with an $\mathrm{X}$-ray generator Radioflex 350 (Rigaku Industrial Corp., Takatsuki) under operating conditions of 260 $\mathrm{kVp}, 15.5 \mathrm{~mA}$ and $0.3 \mathrm{~mm} \mathrm{Cu}+0.5 \mathrm{~mm} \mathrm{Al}$ filters. Four-week-old male NFS mice were exposed weekly to four split dose $(4 \times 1,7 \mathrm{~Gy})$ of $\mathrm{X}$-irradiation. The mice were killed periodically after irradiation, and their thymuses, spleens and femurs were excised. The thymuses and spleens were weighed. Cellularities of the thymus, and bone marrow were examined. Spleen colony-forming units (CFUS) were assessed in the bone marrow. The same parameters were examined in unirradiated male NFS mice used as controls.

Examination of cellularity: A small volume of Dulbecco's medium (Nissui Seiyaku Co. Ltd., Tokyo) was injected intrathymically using a disposable syringe with a $22 \mathrm{G}$ needle, after which the thymus was squeezed with forceps. Thymocytes were washed off of the thymic remnants with 1 or $2 \mathrm{~m} \ell$ of medium using the syringe. Six femurs from three mice were used for the preparation of a marrow cell pool. Femurs were cut at both termini and the bone marrow was then flushed out of the femurs with $1.5 \mathrm{~m} \ell$ (for the femurs of irradiated mice) or $3 \mathrm{~m} \ell$ (for the femurs of unirradiated mice) of Dulbecco's medium containing $20 \mathrm{mM}$ HEPES (N-2-hydroxyethyl piperazine-N-2-ethane sulfonic acid, Wako Pure Chemical Industries 
Table 1. Changes in thymocyte numbers of NFS mice after split dose $(4 \times 1.7 \mathrm{~Gy}) \mathrm{X}$-irradiation

\begin{tabular}{|c|c|c|c|c|c|c|}
\hline \multicolumn{3}{|c|}{ Unirradiated } & \multicolumn{4}{|c|}{ Irradiated } \\
\hline $\begin{array}{c}\text { Age } \\
\text { (Weeks) }\end{array}$ & $\begin{array}{c}\text { Number } \\
\text { of } \\
\text { mice }\end{array}$ & $\begin{array}{c}\text { Cell number } \\
\times 10^{-7} \\
(\text { Mean } \pm \text { SD) }\end{array}$ & $\begin{array}{l}\text { Weeks } \\
\text { after } \\
\text { Irrad. }\end{array}$ & $\begin{array}{c}\text { Number } \\
\text { of } \\
\text { mice }\end{array}$ & $\begin{array}{c}\text { Cell number } \% \\
\times 10^{-7} \\
(\text { Mean } \pm \mathrm{SD})\end{array}$ & $\begin{array}{l}\text { Cell number } \\
\text { (Irrad./ } \\
\text { unirrad.) }\end{array}$ \\
\hline 7 & 5 & $21.7 \pm 2.2$ & $0^{\mathrm{a}}$ & 5 & $5.7 \pm 0.7$ & 26 \\
\hline 11 & 5 & $13.2 \pm 1.3$ & 4 & 10 & $7.9 \pm 4.8^{*}$ & 60 \\
\hline 15 & 4 & $8.4 \pm 1.3$ & 8 & 7 & $5.8 \pm 3.6^{* *}$ & 69 \\
\hline
\end{tabular}

Table 2. Changes in marrow cell numbers of NFS mice after split dose $(4 \times 1.7 \mathrm{~Gy}) \mathrm{X}$-irradiation

\begin{tabular}{|c|c|c|c|c|}
\hline \multicolumn{2}{|c|}{ Unirradiated } & \multicolumn{3}{|c|}{ Irradiated } \\
\hline $\begin{array}{c}\text { Age } \\
\text { (weeks) }\end{array}$ & $\begin{array}{l}\text { Nucleated cell } \\
\text { number } / \text { femur }^{\mathrm{a}} \\
\quad\left(\times 10^{-7}\right)\end{array}$ & $\begin{array}{l}\text { Weeks after } \\
\text { irradiation } \\
\text { (Age, weeks) }\end{array}$ & $\begin{array}{l}\text { Nucleated cell } \% \\
\text { number } / \text { femur }^{a} \\
\left(\times 10^{-7}\right)\end{array}$ & $\begin{array}{l}\text { Cell number } \\
\text { (Irrad./ } \\
\text { unirrad.) }\end{array}$ \\
\hline \multirow{3}{*}{8} & \multirow{3}{*}{1.80} & $0^{\text {b }}(7)$ & 1.00 & 56 \\
\hline & & $1 \quad(8)$ & 1.15 & 64 \\
\hline & & $3(10)$ & 0.98 & 54 \\
\hline \multirow[t]{2}{*}{12} & \multirow{2}{*}{1.80} & $4(11)$ & 1.30 & 72 \\
\hline & & $6(13)$ & 1.70 & 94 \\
\hline \multirow[t]{2}{*}{16} & \multirow[t]{2}{*}{1.88} & $8 \quad(15)$ & 1.45 & 77 \\
\hline & & $10 \quad(17)$ & 1.00 & 53 \\
\hline 20 & 1.68 & 12 (19) & 1.25 & 74 \\
\hline
\end{tabular}

a : Each cell number was obtained by calculation based on the cell concentration of the marrow cell pool prepared from 6 femurs of 3 mice. $\quad b$ : Cell number was examined 24 hours after irradiation.

Ltd., Osaka) using a sterilized disposable syringe with a $22 \mathrm{G}$ needle. After gentle rinsing, tissue debris was filtered out of the cell suspensions with stainless steel mesh. Nucleated cells in the thymic and marrow cell suspensions were counted with a Neubauer hemocytometer after staining with Türk's solution. After the cell count, marrow cell suspensions were used for CFU-S assay.

CFU-S assay : Number of spleen colonyforming unis (CFU-S) in the bone marrow was assessed according to the method of Till and McCulloch [17]. Briefly, appropriate numbers of marrow cells obtained from irradiated and unirradiated male NFS mice were injected intravenously into 3 to 6 female syngeneic recipients which had been pre-irradiated with $9 \mathrm{~Gy}$. Ten days after injection, mice were killed and the spleens of recipients were fixed with Bouin's solution. The numbers of visible colonies on the splenic surfaces were counted with a microscopy model SZ (Olympus Co. Ltd., Tokyo).

Statistical analysis: Student's t-test was applied to the following parameters : the differences between organ weights, intrathymic cellularities and $\mathrm{CFU}-\mathrm{S}$ numbers/femur in irradiated and unirradiated animals.

\section{Results}

Tissue weight: The change in thymic weight after irradiation is represented in Fig. 1. In unirradiated controls, thymic weight reached a maximum (around $100 \mathrm{mg}$ ) at 4-6 weeks of age, then gradually decreased with aging and finally fell below $40 \mathrm{mg}$ in adult mice at 16 or more weeks of age. When mice were 


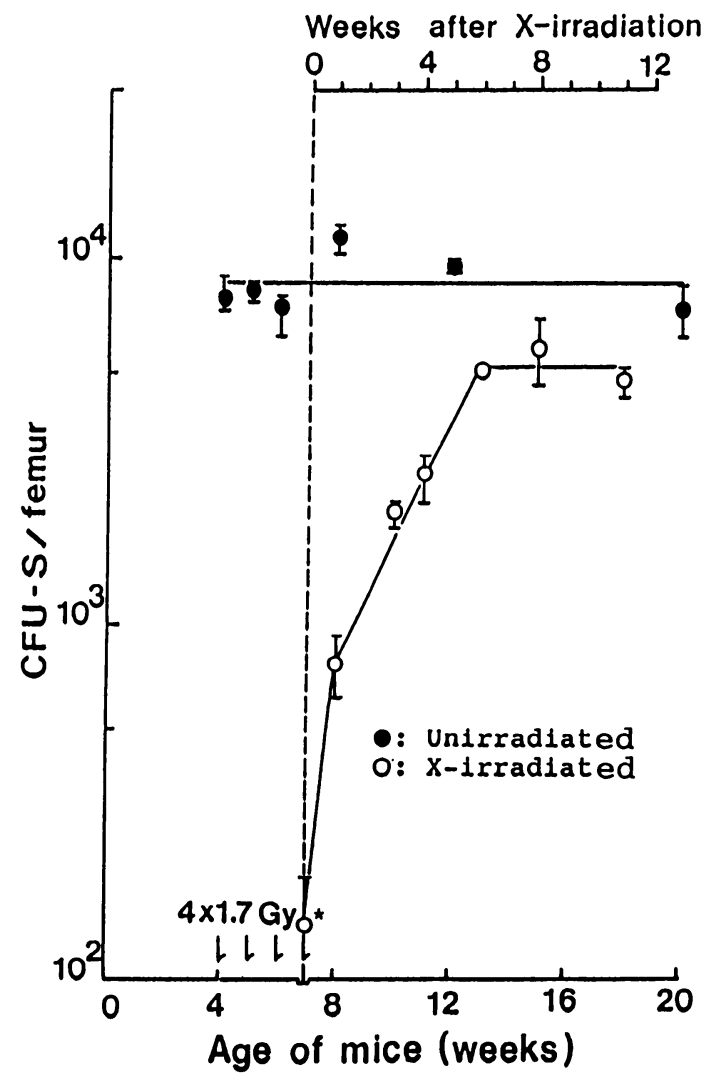

Fig. 3. Femoral CFU-S number recovery in NFS mice exposed to $4 \mathrm{X} 1.7 \mathrm{~Gy}$ of X-irradiation. Appropriate number of marrow cells from 3 donors was injected into 3-6 recipients. Each point represents mean $\pm \mathrm{SD}$. The value with an asterisk was assessed 24 hours after irradiation.

exposed to split doses of $\mathrm{X}$-irradiation, The thymic weight significantly dropped to $29 \mathrm{mg}$ (42\% of age-matched control) 24 hours after the last irradiation $(\mathrm{P}<0.001)$. The thymus continued to decrease in weight during the 3 weeks following irradiation and then slowly recovered. Recovery of thymic weight to a nearly normal level was seen at 8 weeks. The difference between the mean thymic weight at 8 weeks after $\mathrm{X}$-irradiation and that at 16 weeks of age was not significant $(\mathrm{P}>0.5)$.

The recovery pattern of splenic weight was quite different from that of thymic weight (Fig. 2). In unirradiated mice, splenic weight gradually increased and eventually reached a plateau with aging (around 20 weeks of age) . The splenic weight had significantly decreased to $43 \%$ of normal by 24 hours after the last irradiation $(\mathrm{P}<0.001)$ and soon recovered to about $70 \%$ of normal, but the level was significantly lower than normal $(\mathrm{P}<0.02)$. Recovery was delayed thereafter and even 14 weeks after irradiation, the mean splenic weight in $\mathrm{X}$ irradiated mice was significantly lower than that of unirradiated mice 21 weeks of age $(P$ $<0.001)$.

The recovery kinetics of cell numbers in the thymus and bone marrow: Changes in thymic cellularity in irradiated and unirradiated mice are shown in Table 1 . The number of thymocytes in unirradiated mice decreased with aging. In irradiated mice, the number of thymocytes had decreased remarkably $(26 \%$ of the control, $\mathrm{P}<0.001$ ) by 24 hours after the last irradiation, then recovered to $60 \%$ and $69 \%$ of the control at 4 and 8 weeks, respectively, after the last exposure. The recovered levels were, however, significantly lower than those of age-matched controls $(\mathrm{P}<0.05)$.

Changes in marrow cell numbers after split doses of $\mathrm{X}$-irradiation are shown in Table 2 . The decrease in nucleated marrow cell number 24 hours after irradiation was not as marked (56\% of normal) as that of thymocytes. Recovery was slow, but the marrow cell number had almost normalized by $4-6$ weeks after irradiation.

Femoral CFU-S : As shown in Fig. 3, the number of femoral CFU-S had significantly decreased to $1.7 \%$ of the control value (mean number of CFU-S il.c. 6-week-old unirradiated mice) by 24 hours after the last irradiation $(\mathrm{P}<0.001)$, and started to increase logarithmically shortly thereaftrer. However, the recovery had ceased by 6 weeks after $\mathrm{X}$-irradiation, when the CFU-S numbers were at approximately $60 \%$ of the normal level.

\section{Discussion}

In order to understand the marrow-thymus interactions which occur during radiation lymphomagenesis, we examined the recovery kinetics of lymphohematopoietic tissues in NFS mice exposed to split doses on $\mathrm{X}$-irradiation.

The recovery kinetics of splenic weight were very interesting. Splenic weight recovered to some extent shortly after the last irradiation but was delayed thereafter. The delay was connected with reduced $\mathrm{CFU}-\mathrm{S}$ numbers in the bone marrow.

The diminution in nucleated marrow cell 
number 24 hours after exposure was not particularly remarkable ( $56 \%$ of normal), despite the significant decrease in femoral CFU-S number ( $1.7 \%$ of normal) . Bone marrow consists of different lineages of lymphohematopoietic cells in various stages of differentiation, and this could account for most of the surviving cells. Since these surviving cells are quickly depleted as differentiation proceeds, final bone marrow recovery depends upon recovery of the CFU-S number. In NFS mice, normalization of marrow cell numbers required approximately 4-6 weeks. This indicates that the recovery of marrow cell number is closely related to the recovery of CFU-S number.

Thymocytes are derived from prothymocytes in the bone marrow [5]. The thymus depopulated by whole-body $\mathrm{X}$-irradiation is initially repopulated by immature thymocytes which survived the radiation, but prothymocytes migrating from the bone marrow into the thymus after the initial repopulation are essential for recovery. Therefore, thymic weight shows a biphasic recovery in mice exposed to a single sublethal dose of $\mathrm{X}$-irradiation [16]. The first recovery phase starts 3-4 days after exposure and is due to a temporal expansion of immature thymocytes which survived radiation. The second phase, which starts 3 weeks after irradiation, is caused by the proliferation of prothymocytes migrating in from the recovered bone marrow. Biphasic recovery of thymic weight after split doses of $\mathrm{X}^{-}$ irradiation was reported in C57BL mice [2], but has not previously been recognized in NFS mice. Because thymic weight was examined at weekly intervals in our present study, the first small peak might have been overlooked. The thymic weight recovery observed 4 or more weeks after irradiation in NFS mice was, therefore, due mainly to the proliferation of bone marrow cells. Since marrow cell number had recovered to normal and femoral CFU-S number to $60 \%$ of normal by $4-6$ weeks after irradiation, it appears that thymic recovery occurs in parallel with bone marrow recovery. However, the thymus did not normalize in terms of cellularity, indicating that lymphopoiesis in the thymus was significantly impaired by split dose X-irradiation .

Disturbed lymphohematopoiesis in the thymus after split doses of radiation has been reported by many investigators $[10,14]$. Using transplantation of bone marrow cells, Sado et al. showed that thymic degeneration induced by split doses of radiation was essential to the development of neoplastic cells in the B10 murine thymus [15]. Using NFS mice, we showed that thymic recovery following depopulation by split doses of $\mathrm{X}$-irradiation occurred in parallel with bone marrow recovery. These observations suggest the significance of marrow-thymus interactions in radiation-induced lymphomagenesis.

We thank Mr. M. Ikeda and Mr. Y. Ujihara, the staff of the animal breeding facility of the University of OsakaPrefecture, for their attentive animal care.

\section{References}

[1] Boniver, J., Decleve, A., Lieberman, M., Honsik, C., Travis, M., and Kaplan, H. S. (1981). Marrowthymus interactions during radiation leukemogenesis in C57BL/Ka mice. Cancer Res., 41, 390-392.

[2] Boniver, J., Delrez, M., Simar, L. J., and Haot, J. (1973). Modification of the thymic cell population during the development of the radiation-induced lymphoma in mice. Beitr. Path. Bd., 150, 229-245.

[3] Defresne, M. P., Greimers, R., Lanaerts, P., and Boniver, J. (1986). Effects of marrow grafting on preleukemia cells and thymus nurse cells in C57BL/Ka mice after a leukemogenic split-dose irradiation. $J$. Natl. Cancer Inst., 17, 1079-1085.

[4] Haran-Ghera, N. (1978). Spontaneous and induced prelymphoma cells in C57BL/6 mice : Brief communication. J. Natl. Cancer Inst., 66, 707-710.

[5] Kadish, J. L. and Bash, R. S. (1976). Hematopoietic thymocyte precursors. I. Assay and kinetics of the appearance of progeny. J . Exp. Med., 143 1082-1099.

[6] Kaplan, H. S. (1950). Influence of thymectomy, splenectomy and gonadectomy on induction of radiation-induced lymphocyte tumors in strain C57Black mice. J. Natl. Cance Inst., 11, 83-90.

[ 7 ] Kaplan, H. S. (1967). On the natural history of the murine leukemias: Presidental address. Cance Res., 27, 1325-1340.

[8] Kaplan, H. S., Brown, M. B., and Paull, J. (1953). Influence of bone marrow injection on involution and neoplasia of mouse thymus after systemic irradiation. J. Natl. Cance Inst., 14, 303-316.

[9] Mori, N. and Takamori, Y. (1989). The genesis of Thy-1- lymphomas in NFS mice exposed to Xirradiation. Radiat. Res., 117, 35-46.

[10] Muto, M., Kubo, E., and Sado, T. (1985). Cellular events during radiation-induced thymic leukemogenesis in mice: Abnormal $\mathrm{T}$ cell differentiation in the thymus and defect of thymocyte precursors in the bone marrow of the split-dose irradiation. J. Immunol., 134, 2026-2031.

[11] Muto, M., Kubo, E., and Sado, T. (1987). Development of prelymphoma cells committed to thymic lymphomas during radiation-induced thymic lymphomagenesis in B10 mice. Cancer Res., 47, 3469-3472.

[12] Okumoto, M., Nishikawa, R., Iwai, M., Iwai, Y., 
Takamori, Y., Niwa, O., and Yokoro, K. (1990). Lack of evidence for the involvement of type- $\mathrm{C}$ and type-B retroviruses in radiation leukemogenesis of NFS mice. Radiat. Res., 121, 267-273.

[13] Okumoto, M., Nishikawa, R., Takamori, Y., Iwai, Y., Iwai, M., and Tsubura, Y. (1985). Endogenous type-C viral expression during lymphoma development in irradiated NFS mice. Radiat. Res., 104, 153 -165 .

[14] Pazmiño, N, H., McEvan, R., and Ihle, J. N. (1978). Radiation leukemia in $\mathrm{C} 57 \mathrm{BL} / 6$ mice. III Correlation of altened expression of terminal deoxynucleotidyl transferase to induction of leukemia. J . Exp. Med., 148, 1338-1350.

[15] Sado, T., Kamisaku, H., and Kubo, E. (1991). Bone marrow-thymus interactions during thymic lymphomagenesis induced by fractionated radiation exposure in B10 mice: Analysis using bone marrow transplantation between Thy 1 congeneic mice. $J$. Radiat. Res., Supplement 2, 168-180.

[16] Takada, A., Takada, Y., Huang, C. C., and Am brus, J. L. (1968). Biphasic pattern of thymic regeneration after whole-body irradiation. J. Exp. Med., 129, 445-457.

[17] Till, J. E. and McCulloch, E. A. (1961). A direct measurement of the radiation sensitivity of normal mouse bone marrow cells. Radiat. Res., 14, 213-222.

[18] Wallis, V., Davies, A. J. S., and Koller, P. C. (1966). Inhibition of radiation-induced leukemia by the injection of haematopoietic tissue: A study of chimaerism. Nature, 210, 500-504.

\title{
X線分割照射 NFS 系マウスにおけるリンパ造血系組織の回復過程
}

\author{
森展子・高森康彦*・奥本正昭・西川量介 \\ 大阪府立大学附属研究所応用生体科学部門 \\ *大阪府立大学農学部獣医放射線学教室
}

\section{放射線リンパ腫高発系の NFS 系マウスに，X線を}

$1.7 \mathrm{~Gy}$ づつ 4 回分割照射し, 約 3 カ月間リンパ造血系 組織の回復を調べた。最終照射24時間後の胸腺重量,

脾脭重量はほほ同程度に減少した（正常值の $42 \%$ と 43 $\%)$ 。胸腺重量は照射 3 週後まで減少を続け, 次第に 回復し, 8 週後にはほほ正常值に近づいたのに対し,

脾臓重量は照射 1 週後には正常値の $70 \%$ に回復した ものの, 以後の回復は遅滞した。照射 24 時間後の胸腺 の細胞数は著しく減少（正常値の $26 \%$ ) し， 4 週後, 8 週後でも低いレベルであった（正常值の $60 \%$ と69
\%)。骨髄の有核細胞数は照射24時間後には胸腺ほど 著しく減少せず (正常值の56\%)，4-6週後までにほほ 正常值となった。骨髄の CFU-S(脾コロニー形成ユニ ット) 数は照射 24 時間後に正常值の $1.7 \%$ に隇少し, す ぐに対数的に增殖をはじめた。しかしそれは照射 6 週 後に正常值の $60 \%$ に達したところで停止した。この結 果，分割照射したNFS 系マウスの胸腺，脾荿，骨餚 におけるリンパ形成と造血の異常が長期におよぶこ と，またその異常は骨䯑逍の CFU-S 数の減少に結びつ いていることが示唆された。 